3. Лобур М. В. Комп’ютерна графіка в САПР КОМПАС-3D. / М.В. Лобур // Львів : Львівська політехніка, 2012 р. - С. 232.

4. Толюпа С. В. Резонансні методи отримання і використання інформації в радіотехнології. / І. Р. Пархомей, В. А. Дружинін, В. С. Наконечний // Монографія. - Видавництво «Логос». - К. : ДУТ, 2013 р. - 146 с.

5. Отиченко О. М. Вплив попередньої магнітної обробки на динаміку розчинності композиційного гідроксиапатитного матеріалу / О. М. Отиченко Н. Д. Пінчук, О. Р. Пархомей та ін. // Журнал «Наноструктурное материаловедение». - К. : НАНУ, 2014 р. - № 2. - С. 45-52.

6. Отиченко О.М. Вплив фазового складу та дисперсності фаз на біохімічні властивості легованого наномагнетитом гідроксиапатиту / О. М. Отиченко, О. Р. Пархомей, І. В. Уварова // Журнал «Наноструктурное материаловедение». - К. : НАНУ, 2015 р. - № 1. - С. 86-92.

7. Уварова I. В., Максименко В. Б. Біосумісні матеріали для медичних виробів навч. посібн. - К. : КіМ, 2013. -231 с.
УДК 621.391 .68

I. Р.Пархомей, Н. В.Цьопа, Є. О. Батрак

\section{ОБГРУНТУВАННЯ ПАРАМЕТРІВ АНТЕН СИСТЕМ АВТОМАТИЧНОГО РАДІОМОНІТОРИНГУ}

Анотація: Підвищення ефективності радіолокації радіолокащійних об'єктів зі штучно зниженою ефективною площею віддзеркалення у значній мірі ускладнюється інформаційною невизначеністю щодо параметрів руху об'єкту. В умовах неможливості усунення інформаційної невизначеності доцільно застосовувати засоби итучного інтелекту, які мають здатність накопичувати узагальнювати та використовувати знання з метою оптимізації керування. Для синтезу систем керування зі штучним інтелектом використовуються апарат нечіткої математики,в основі якого лежить теорія нечітких множин. Припустивши що система керування антени також прачює в умовах неінформаційної невизначеності, можна провести ї̈ удосконалення Оскільки для контуру керування антени важлива не стільки пеленгаційна помилка скільки швидкість ї̈ зміни у функиіі кутів пеленгу об'єкту - тобто крутизна пеленгаційної помилки - то для компенсаиі ї̈ впливу необхідне введення функиії (програми) компенсаиї паразитного зворотного зв'язку. Крім функції врахування компенсації пеленгаційної помилки в антенохвильових системах вводиться структурна компенсачія, яка визначає зворотній знак паразитного зв'язку. Сполучення функиіональної і структурної компенсаиії дозволяє забезпечити стійкий процес супроводження радіолокаиійних об'єктів із допустимою динамічною помилкою тобто підвищити їх ефективність.

Ключові слова: ефективна площа віддзеркалення, система керування антеною, антено-хвильова система, пеленгачійна помилка, інформачійна невизначеність

\section{Вступ}

Один із шляхів підвищення ефективності радіолокації радіолокаційних об'єктів зі штучно зниженою ефективною площею віддзеркалення (ЕПВ) є оптимізація процесу їх супроводження. Вирішення цієї проблеми у значній мірі ускладнюється інформаційною невизначеністю щодо параметрів руху об'єкту головним чином за рахунок поглинання радіосигналу та складності технічної реалізації отриманих оптимальних алгоритмів керування в системі керування антеною (СКА).

() І. Р.Пархомей, Н. В.Цьопа, Є. О. Батрак 
Окрім шумових складових вхідний сигнал також містить хибну складову параметрів руху об'єкту, що виникає завдяки флуктуації сигналу резонансного збудження [1]. Ці обставини, в свою чергу, призводять до виникнення неусувної інформаційної невизначеності стосовно параметрів руху об'єкту.

В умовах неможливості усунення інформаційної невизначеності доцільно застосовувати засоби штучного інтелекту які мають здатність накопичувати узагальнювати та використовувати знання з метою оптимізації керування. Одним 3 напрямків такої оптимізації $\epsilon$ накопичення евристичних знань щодо закономірності формування керуючих впливів у вигляді асоціативних пар «стимулреакція», узагальнення цього досвіду у «активній пам'яті», накладання досвіду на асоціативну вибірку відповідного керування та подаванні на вхід стимулу, що охоплює значення параметрів стану об’єкту керування.

\section{Основна частина}

Для синтезу систем керування зі штучним інтелектом використовується апарат нечіткої математики, за основу якого приймається не класична теорія множин, а теорія нечітких множин. Необхідність використання апарату нечіткої математики зумовлена тим, що в умовах інформаційної невизначеності стану об'єкту керування стає неможливим здійснювати опис впливів, які здійснюються на нього, традиційними математичними формалізмами, які характеризуються однозначністю інтерпретації $[1,2]$.

Невиключно, що система керування антеною також працює в умовах інформаційної невизначеності, тобто, може бути удосконалена.

Ідентифікацію (визначення) ситуацій виконує блок оцінки станів на основі інформації про кутову швидкість лінії візування ракета - ціль, що надходить від антено-хвильової системи (АХC). При порівнянні цієї інформації з функцією приналежності блок визначає ступінь належності термів параметрів стану, який оцінюється. Для формування функцій приналежності, яка використовується в системі, будується залежність між виміряними значеннями кута лінії візування об’єкту та максимальними допустимими значеннями.

Таким чином, кінцевий результат створюється як середньовагоме значення для кожного правила з використанням в якості ваги значень істинності правил.

Для контуру СКА важлива не стільки пеленгаційна помилка внесена флуктуацією сигналу скільки швидкість ії зміни у функції кутів пеленга об’єкту, що характеризує крутизну пеленгаційної помилки (ПП)
Максимальне значення ПП для контуру керування антеною за технічним завданням (Т3) не повинне перевищувати 30' (значення крутизни ПП в площині розвороту АХC оптимальне якщо не більше 0,04 рад/с (при усередненні на ділянці 0,01 град і в секторі 2,5²) [3].

Вплив ПП, що створюється флуктуацією сигналу збудження полягає в тому, що наприкінці виникає паразитний зворотній зв язок (33) по коливанню корпусу радіолокаційної станції (РЛС) 3 коефіцієнтом підсилення пропорційним крутизні ПП, а також у взаємозв'язку каналу керування з помилками пеленга основного каналу від кута пеленга в додатковому каналі.

Для компенсації впливу флуктуації сигналу збудження необхідно вжити наступні заходи: введення функції (програми) компенсації позитивного зворотного зв'язку по апреорії інформації про залежність цих помилок від кутів пеленга цілі $(\varepsilon, \beta)$.

Характер зміни ПП при вертикальній поляризації електромагнітної хвилі підсвічування об'єкту є монотонним, що доцільно використовувати при супроводженні низько-літаючого об'єкту (НЛО), а кругову поляризацію - доцільно використовувати у всіх інших випадках [4]. 3 огляду на цей факт, і те що вплив флуктуації сигналу на СКА найбільш впливово позначається на великих висотах супроводження об'єкту можна обмежитися введенням функції компенсації тільки для кругової поляризації електромагнітної хвилі підсвічування об’єкту.

Пеленгаційна характеристика РЛС має розкид, зумовлений технологічними особливостями виготовлення обтічника, точністю вимірів, а також відмінністю умов, що мають місце в окремих зразках.

Помилки пеленга $\Delta \varepsilon\left(\varepsilon_{\mathrm{s}}, \beta_{\mathrm{r}}\right)$ і $\Delta \beta\left(\varepsilon_{\mathrm{m}}, \beta_{\mathrm{r}}\right)$ через вплив флуктуації сигналу повинні вводиться в систему керування антеною зі зворотним знаком. Математичне очікування набору характеристик кожного обтічника та інша інформація повинна вводиться в пам'ять бортової обчислювальної системи (БОС) РЛС [5].

Запам'ятоване значення $\Delta \varepsilon\left(\varepsilon_{\mathrm{s}}, \beta_{\mathrm{r}}\right)$ і $\Delta \beta\left(\varepsilon_{\mathrm{s}}, \beta_{\text {г }}\right)$ у БОС враховується з кроком:

$$
n=\left\{\begin{array}{l}
2,5^{\circ} \text { при }\left|\varepsilon_{\mathrm{r}}\right| \leq 12,5^{\circ},\left|\beta_{\mathrm{r}}\right| \leq 12,5^{\circ} ; \\
5^{\circ} \text { при }\left|\varepsilon_{\mathrm{r}}\right|<30^{\circ},\left|\beta_{\mathrm{r}}\right|>12,5^{\circ} ; \\
7,5^{\circ} \text { при }\left|\varepsilon_{\mathrm{r}}\right|>30^{\circ},\left|\beta_{\mathrm{r}}\right|>12,5^{\circ} ;
\end{array}\right.
$$

де $\varepsilon$ - кут місця об'єкту; $\beta$ - азимут об'єкту. 
Між вузловими точками значення $\Delta \varepsilon\left(\varepsilon_{\mathrm{v}}, \beta_{\mathrm{r}}\right)$ i $\Delta \beta\left(\varepsilon_{\mathrm{m}}, \beta_{\mathrm{r}}\right)$ інтерполюються в поточні значення $\Delta \varepsilon\left(\varepsilon_{\mathrm{s}}, \beta_{\mathrm{r}}\right), \Delta \beta\left(\varepsilon_{\mathrm{m}}, \beta_{\text {г }}\right)$ після перетворення за допомогою оператора Лапласа $(p)$

$$
\frac{p}{(1+0,063 p) \cdot(1+0,025 p)^{2}}
$$

де (2) опис апроксимованої ланки ПП на вихід АХС та оптимальної кутової швидкості лінії візування на виході АХС. Точність завдання $\Delta \varepsilon\left(\varepsilon_{\mathrm{m}}, \beta_{\mathrm{r}}\right)$ і $\Delta \beta\left(\varepsilon_{\mathrm{m}}, \beta_{\text {г }}\right)$ у вузлових точках складає $\pm 5 \%$.

Очікувані значення некомпенсованої крутизни пеленгаційної характеристики АХС після введення функції компенсації складе для РЛС супроводження $\pm 0,02- \pm 0,025$.

Крім функції врахування комплексної пеленгаційної помилки АХС здійснюється на основі даних, отриманих у заводських умовах методом вимірювання і вводиться у систему шляхом структурної компенсації.

Структурна компенсація здійснюється визначенням зворотного знака паразитного 33 в автоматичному контурі керування антеною. Для визначення знака градієнта пеленгаційної характеристики АХС використовується сигнал кутової швидкості візування об’єкту після введення функції компенсації ПП і виміру сигналу швидкості зміни кута пеленга об’єкту за допомогою тахогенератора (ТГ) привода СКА [6].

Сигнал по якому визначається знак крутизни пеленгаційної характеристики надходить через фільтр $W_{\phi}$ із приймальної системи РЛС (3).

$$
W_{\phi}=\frac{p^{2}}{(1+0,2 p) \cdot(1+0,1 p)^{2}}
$$

де $W_{\phi}$ - передаточна функція фільтра

На нечіткий логічний регулятор, при збігу знаків сигналів на вході $W_{\phi}$, підключається штучний від'ємний зворотній зв'язок, а при розбіжності - позитивний зворотній зв'язок.

Блок зворотної компенсації реалізується в БОС і видає наступні команди підсумовані з кутовою швидкістю лінії візування

де $\dot{\varepsilon}$ - швидкість зміни кута місця; $\dot{\beta}$ - швидкість зміни азимута.

Команди керування з урахуванням компенсації впливу флуктуацій сигналу резонансного збудження записуються у вигляді

$$
\begin{aligned}
& \lambda_{c_{1}}=y_{\phi}\left(\omega_{z \mathrm{r}}-\frac{p \Delta \varepsilon\left(\varepsilon_{\mathrm{r}}, \beta_{\mathrm{r}}\right)}{(1+0,063 p) \cdot(1+0,025 p)}+\eta_{1}\right) \\
& \lambda_{c_{2}}=-y_{\phi}\left(\omega_{y \mathrm{r}}-\frac{p \Delta \varepsilon\left(\varepsilon_{\mathrm{r}}, \beta_{\mathrm{r}}\right)}{(1+0,063 p) \cdot(1+0,025 p)}+\eta_{2}\right)
\end{aligned}
$$

де $\lambda$ - команда керування; $y_{\phi}-$ коефіцієнт передачі фільтру; $\eta_{1,2}-$ початкова помилка визначення пеленга об'єкта; $\omega$ - кутове прискорення об'єкту.

Схему структурної компенсації можна зобразити як випадок відомого самонастроювання системи компенсації крутизни ПП на основі виміру їі значення, тобто іï можна зобразити як релейну самонастроювальну систему, що діє як розімкнена на основі виміру тільки знака градієнту пеленгаційної характеристики. Час потрібний на оцінку знака градієнту пеленгаційної характеристики менший ніж на оцінку його значення, а для зазначених РЛС це $є$ найбільш важливим, тому що процес супроводження радіолокаційних об'єктів зі штучно зниженою площею віддзеркалення має малу тривалість за рахунок суттєвого зменшення глибини зони до пошуку.

\section{Висновки}

Наведення АХС РЛС на радіолокаційний об'єкт зі штучно зменшеною площею віддзеркалення можливо за допомогою адаптивного методу, який грунтується на пристосуванні системи керування антеною до умов інформаційної не- 
визначеності, яка спричиняється флуктуацією сигналу збудження радіопоглинаючого покриття радіолокаційного об'єкту.

Оцінка параметричної чутливості синтезованої системи керування антеною на математичній моделі, реалізованої за допомогою ПЕОМ, показує достатній ступінь «грубості» до похибок виміру параметрів руху радіолокаційного об'єкту.

Визначення знака паразитного зворотного зв'язку відбувається в основному правильно, якщо він не змінюється на відрізку часу, на якому вимірюються параметри руху об'єкту.

Сполучення функціональної і структурної компенсації дозволяє забезпечити стійкий процес супроводження із допустимою динамічною помилкою.

\section{Список використаних джерел}

1. Артемьев В. М. Основы автоматического управления систем радиоэлектронных средств. / Артемьев В.М., Яшулен Е.А. - М.: Воениздат, 1984. - 86 с.

2. Архангельский В. И. Системы фуцци-управления. / Архангельский В.И. - К. «Техніка», 1997. - 98 с.

3. Воскресенский Д. И. Радиооптические антенные решетки. / Д. И. Воскресенский, А. Ю.Гринев, Е. Н. Воронин. - М.: «Радио и связь», 1986. - 120 с.

4. Востриков A. K. Радиолокационные станции сопровождения цели и визирования./ А. К. Востриков, А. Н.Раинкин - К.: КВЗРИУ, 1974. - 84 с.

5. Гирко В.Л. Теория электрических систем управления. / В. Л.Гирко. - К. : «Лыбидь», 1990. - $168 \mathrm{c}$

6. Вуд П. Анализ и проектирование зеркальных антенн. / П. Вуд. пер. с англ. М. : «Радио и связь», 1984. - 202 с.
УДК 621.391 .68

I. Р. Пархомей

\section{АДАПТИВНІ БАГАТОПОЗИЦЙНН СИСТЕМИ РАДІОЛОКАЦІї}

Анотаиія: В роботі розглянуті методи, які можуть бути реалізовані на етапах виявлення і супроводження РЛС сучасних радіолокаиійних об'єктів

Ключові слова: ефективна площа віддзеркалення, резонансне збудження кристалічної структури, радіопоглинаюче покриття.

\section{Вступ}

В цей час існує ряд науково-технічних проблем, які пов'язані зі складністю одержання радіозображень (Р3) високого розділення і якості в різних режимах спостереження, у тому числі й у передній зоні огляду бортових радіолокаційних засобів (БРЛЗ) систем радіобачення (СРБ).

\section{Основна частина}

Вирішення даної проблеми можливе за рахунок реалізації режиму багатопозиційного прийому інформації в системах радіобачення (СРБ) з керованою групою дистанційно пілотованих літальних апаратів (ДПЛА), що виконують функцію носіїв БРЛЗ (рис. 1).

Метою даної роботи $є$ проведення аналізу особливостей функціонування даних радіотехнічних систем в режимі багатопозиційного прийому радіолокаційної інформації від об’єктів моніторингу.

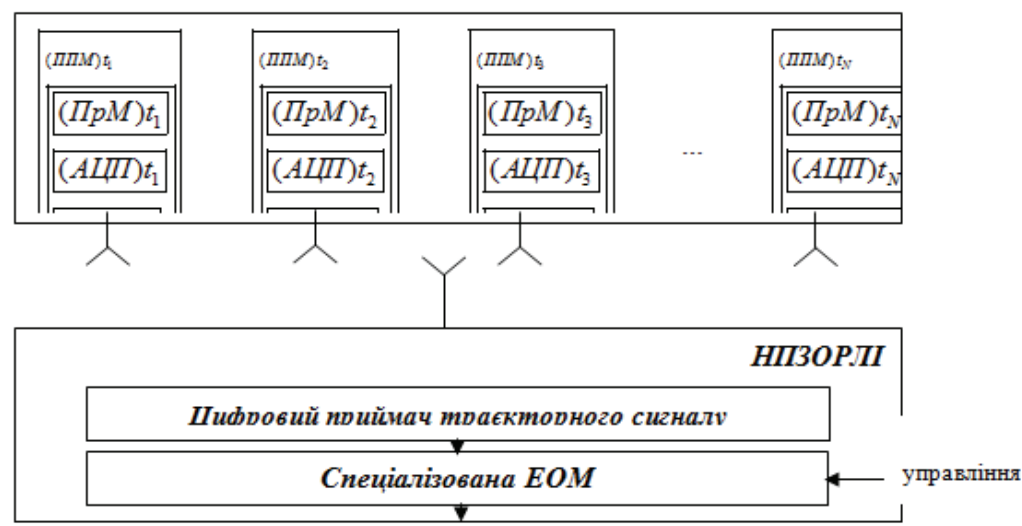

Рис. 1. Спрощена структурна схема СРБ з керованою групою ДПЛА

де $(\text { ППМ })_{t k}-$ приймально-передавальний модуль БРЛЗ ДПЛА, який опромінює (ㄱ І. Р. Пархомей 